\title{
Investigation of Antibacterial Property of Cockroach Wing Surface against Pseudomonas aeruginosa Strains
}

\author{
Karthika Priya $\mathrm{R}^{1}$, Banu Pradheepa Kamarajan ${ }^{1,2}$, Muthusamy Ananthasubramanian ${ }^{3 *}$ \\ \{karthikapriyarajaram@gmail.com ${ }^{1}$, banu150888@gmail.com ${ }^{2}$, biosubramanian@gmail.com ${ }^{3}$ \} \\ Department of Biotechnology, PSG College of Technology, Coimbatore, India ${ }^{1}$, Department of \\ Biomedical Engineering, Sri Ramakrishna Engineering College, Coimbatore, India ${ }^{2}$
}

\begin{abstract}
Bacterial infection is a menace in the healthcare sector. Bacteria responsible for nosocomial infections have developed multi-drug resistance. This urges the need for adopting physical means to deter bacterial attachment. This study investigated the bactericidal activity of surface topography of cockroach wing against strains of Pseudomonas aeruginosa. The results indicated that the nanopore topography was found to reduce the bacterial attachment and their viability till $7 \mathrm{~h}$, suggesting that nanopore topography could be a potential antibacterial surface.
\end{abstract}

Keywords: Pseudomonas aeruginosa, nanopore, viability, bactericidal, cockroach.

\section{Introduction}

Biomaterial implants are used to treat trauma, tumor resection or wear in the human body. Biomaterials replace or augment the functioning of the damaged organ either temporarily or permanently. Use of foreign body (biomaterial) inside the host system invites bacterial infections, which is termed as Biomaterial Associated Infection (BAI). Bacteria primarily attaches to the surface of the implant, multiplies and eventually forms a biofilm, leading to implant disfunctioning and demands revision surgery. Infection in total hip replacement after primary procedure was $1.7 \%$, which increased to $3.2 \%$ after the after revision procedure [1]. In the United States the rate of infection in hip arthroplasty showed annual increase at a rate of $5 \%$ from 1990 to 2004. Conventional techniques employ antibiotics such as amoxicillin, cephalexin, gentamycin, sulfamethoxazole, ciprofloxacin and vancomycin.However, numerous bacterial species have developed multidrug-resistance [1].

Smart surfaces like Cu-bearing stainless steel surface, Ag releasing hydrogels, antibiotics releasing bone cements [10], and implant surface coated with N,N-dodecyl methylpolyethylene imine were used to combat BAI. These smart surfaces with antibiotics have uncontrolledburst release, poor durability and long leaching time that leads to further complications [7].

Based on the reports of Ivanova et al.2012, natural surfaces are being exploited for their antimicrobial properties. Insects have evolved to possess super hydrophobic wing surfaces to minimize or prevent the attachment of contaminants on their surface. The super hydrophobicity also possesses self-cleaning properties. Insects follow different strategies to evade the attachment of contaminants. The bactericidal and antifouling nature of cicada and dragon fly wings are well studied [2]. 
The wing surfaces of cicada and dragonfly consists of nanopillars on the surface that contribute for its super hydrophobicity. These nanopillars were reported to rupture the cell walls of bacteria that come in contact $[4,8]$. This bactericidal activity was reported to be due to the physical property of the nanopillars and not its chemical property[4].

Here we report the antibacterial property of the cockroach wings against the Pseudomonas aeruginosa strains namely, PAO1 and ATCC 9027.

\section{Materials And Methods}

\section{A. Sample preparation}

Cockroaches were collected from the household areas in Madurai, India. The wings rinsed with Millipore water were air-dried followed by UV irradiation for 20 minutes. The wings were cut into circular discs of $1 \mathrm{~cm}$ diameter and stuck to 48 -well plate (fig. 1), with glass coverslip as control [3].

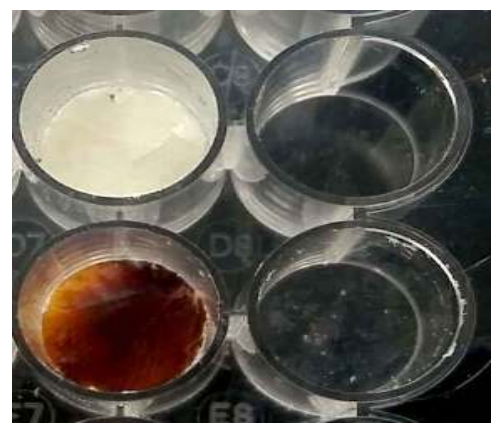

Fig. 1: Glass cover slip and wings fixed to the bottom of a 48 well-plate.

\section{B. Surface Characterization of Wing}

\section{1) Physical characterization}

The cleaned and dried wings were sputter coated with gold nanoparticles (Emitech Mini Sputter coater) and visualized under Scanning Electron microscope (ZEISS).Various regions of the wings were focused to confirm the morphological consistency.

2) Surface wettability

Static water contact angles were measured on cockroach wings using KRUSS-Drop Shape Analyzer DSA 25E. Static water contact angle of the wing surface was measured using $10 \mu 1$ of water droplet.

3) Chemical Characterization

EDAX (Bruker) was used to determine the elemental composition of the wings. The elements present on the wing surfaces were detected from the spectra. The relative atomic percentage of the elements was determined.

C. Preparation of bacterial culture

The strains of Pseudomonas aeruginosa PAO1 and ATCC 9027 (MTCC 1688) were procured from NCIL, Pune and MTCC, Chandigarh, India. Single colony of the cultures were inoculated into the nutrient broth and cultured overnight in a shaker incubator at $120 \mathrm{rpm}$. After incubation, the cells were pelleted by centrifuging at 7,000 rpm for $6 \mathrm{~min}$. The pelleted cells were resuspended in PBS (pH 7.4) to reach $\mathrm{OD}_{600 \mathrm{~nm}}$ to 0.1 . 
D. Analysis of Bacterial viability on cockroach wing surface

$P$. aeruginosa cultures suspended in PBS were loaded on to the wells of 48 well-plate containing a $1 \mathrm{~cm}$ diameter cockroach wings and glass cover slip. This plate was incubated at $37{ }^{\circ} \mathrm{C}$. Readings were taken at discrete time intervals of $0.5 \mathrm{~h}, 1 \mathrm{~h}, 2 \mathrm{~h}, 7 \mathrm{~h}, 24 \mathrm{~h}$ and $48 \mathrm{~h}$. Postincubation, the cultures were diluted 100 times with PBS pH 7.4. $10 \mu$ of this diluted sample was used for plating on nutrient agar plates [3]. Meanwhile, to determine the number of viable cells attached to thesubstrate, the substratum was rinsed in PBS pH 7.4 and sonicated in $2 \mathrm{ml}$ PBS pH7.4 for 10 min using a bath type sonicator (Ultra Sonic cleaner Lab Companion UCP02). $10 \mu \mathrm{l}$ from this sample was used for plating on nutrient agar plate. The plates were incubated over night at $37{ }^{\circ} \mathrm{C}$. The colonies were counted and the relative colony forming units per $\mathrm{ml}$ were calculated using the formula below.

Colony forming units $=$ (no. of colonies*dilution factor $) /$ Volume used for plating

E. Imaging of bacterial attachment

The surface topographies of the wings and bacterial attachment on the wings were visualized using SEM. The coverslips and wings obtained after incubation with $P$. aeruginosa strains were used for SEM imaging. The bacterial cells attached to the coverslip and wing were prepared for SEM imaging using the procedure described earlier [5]. The samples were then air-dried. The dehydrated samples were then sputter coated with gold and mounted onto the studs for imaging in SEM.

\section{F. DNA Quantification}

The DNA in the suspension was quantified without disrupting the intact cells. This is used as an indirect measure of dead cells. The bacterial cultures suspended in PBS were incubated with coverslip and wing at $37^{\circ} \mathrm{C}$. After $30 \mathrm{~min}, 1 \mathrm{~h}, 2 \mathrm{~h}, 7 \mathrm{~h}, 24 \mathrm{~h}$ and $48 \mathrm{~h}$, the suspension from the 48 well-plate was collected and centrifuged to pellet down the cells. The DNA released into the supernatant was quantified using the phenol:choloroform:isoamyl alcohol procedure [9].

\section{G. Estimation of EPS}

In order to estimate the amount of extracellular polysaccharides (EPS) produced by both Pseudomonas aeruginosa PAO 1 and Pseudomonas aeruginosa ATCC 9027 on the wing surfaces of cockroach, the EPS produced on the substrate was extracted and then quantified according to the method previously method described by Dubois [11].

\section{RESULTS AND DISCUSSION}

A. Physical Characterization

1) Surface architecture

The surface topography of cockroach wing showed nano pore structures arranged in a flower like pattern (Fig. 2). The diameter of pores varied between 189.4 and $303.4 \mathrm{~nm}$.

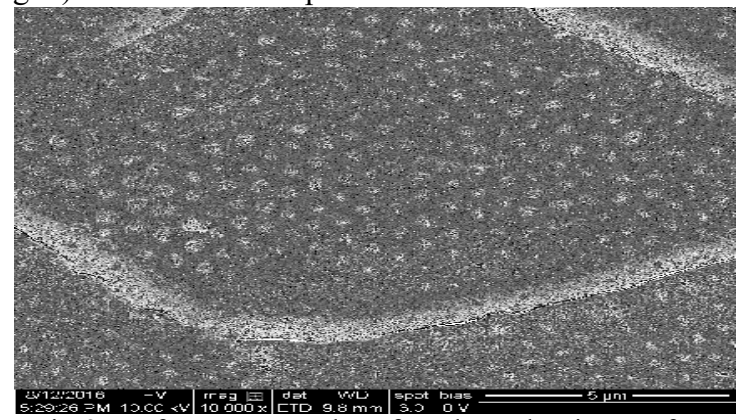

Fig.2.Surface topography of cockroach wing surface 
Scanning Electron Microscopic image cockroach wing surface at $10000 \mathrm{X}$ magnification. Nano pore architecture with diameter varying between 189.4 and $303.4 \mathrm{~nm}$ was distributed throughout the wing surface.

2) Surface wettability

The surface hydrophobicity was tested using static water contact angle. Water contact angle on cockroach wing surface varied between $92^{\circ}$ and $99^{\circ}$ (fig. 3), indicating the hydrophobic nature of the surface.
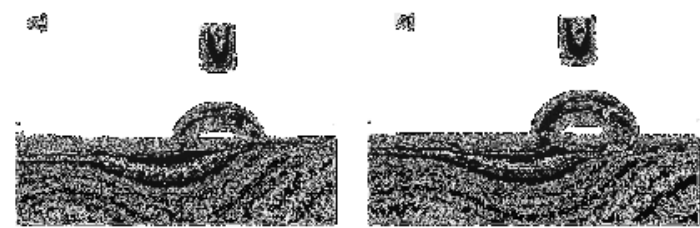

Fig.3. Surface wettability analysis on cockroach wing surface. Water contact angle measurement on the wing surfaces ranged between (a) 92 degrees and (b) 99 degrees indicated the hydrophobicity of the surface.

\section{B) Chemical Characterization}

The EDX analysis allowed the determination of the elemental composition of cockroach wing (fig. 4). Previous studies [3,4]indicated that the wing surfaces were composed of hydrophobic long chain lipids.

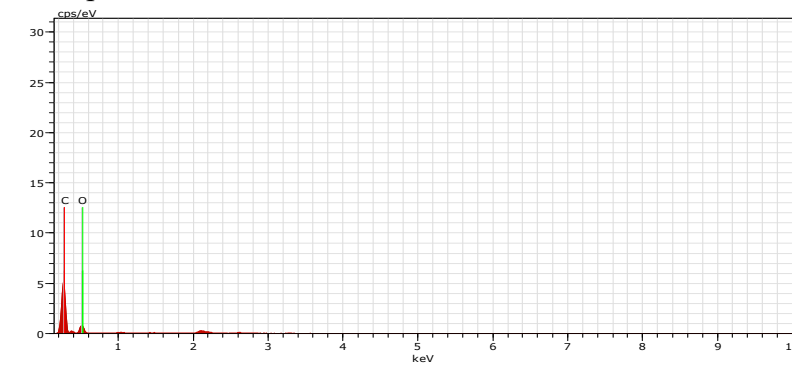

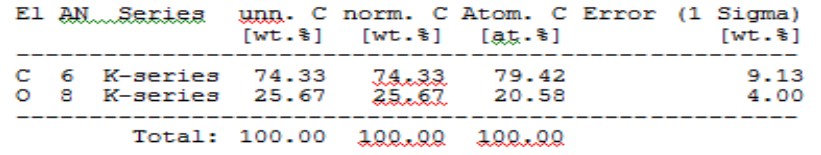

Fig 4.EDAX spectra of cockroach wing

C) Viability on cockroach wing surface

The viable bacteria on the control and wing surface were estimated using colony counting technique. The viability results (fig. 5) indicated that $P$. aeruginosa PAO1 showed a decline in the viability from $30 \mathrm{~min}$ to $7 \mathrm{~h}\left(8 \times 10^{5} \mathrm{cfu} / \mathrm{mL}\right)$. After $7 \mathrm{~h}$, the viable cell count was observed to increase both on coverslip and wing showing $40 \times 10^{5} \mathrm{cfu} / \mathrm{mL}$ and $12 \times 10^{5} \mathrm{cfu} / \mathrm{mL}$ at $48 \mathrm{~h}$ on coverslip and wing respectively.

$P$. aeruginosa ATCC 9027 also showed decline in viable cell count till $7 \mathrm{~h}\left(200 \times 10^{5}\right.$ $\mathrm{cfu} / \mathrm{mL}$ ), after which the viable cells increased to $700 \times 10^{5} \mathrm{cfu} / \mathrm{mL}$ on coverslip at $48 \mathrm{~h}$. $P$. aeruginosa ATCC 9027 on wing surface showed decline till $7 \mathrm{~h}\left(80 \times 10^{5} \mathrm{cfu} / \mathrm{mL}\right)$, after which the viable cell count increased to $450 \times 10^{5} \mathrm{cfu} / \mathrm{mL}$.

The viabiliy was lesser on wing than on the coverslip in both the strains, with PAO1 exhibiting lower viability on the wing surface. The viability pattern suggested that nanopore 
surface topography does exhibit bactericidal activity. Similar result was reported by Feng et al. 2015 when studied bacterial viability on the aluminium surfaces with nanopore topography.

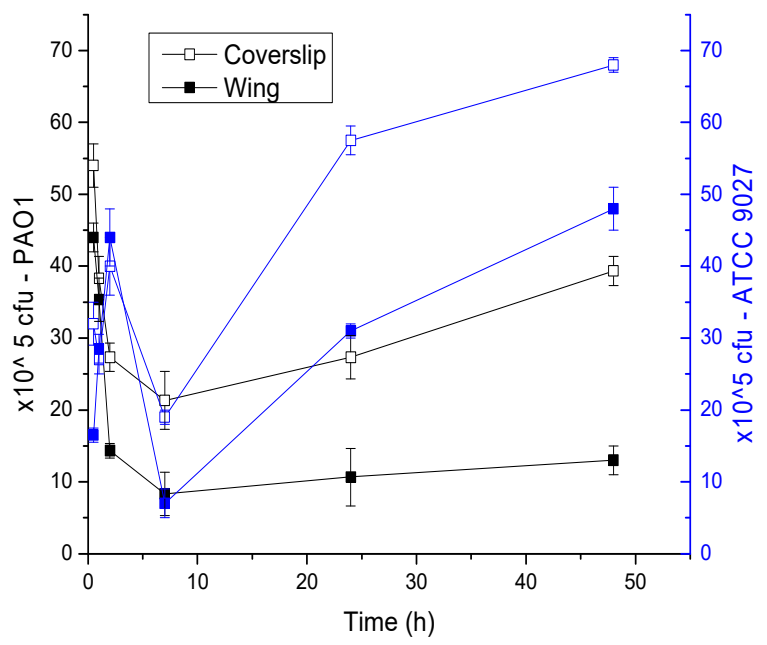

Fig. 5. Viability of $P$. aeruginosa strains on the coverslip and wing from $30 \mathrm{~min}$ to $48 \mathrm{~h}$.

D) Imaging of Bacterial Attachment

$P$. aeruginosa strains attached to the wing surface after $7 \mathrm{~h}$ and $24 \mathrm{~h}$ of incubation were visualized and imaged under SEM (fig. 6). The images indicate that number of PAO1 attached to the wing surface was lesser than that of ATCC 9027 at tested time periods.

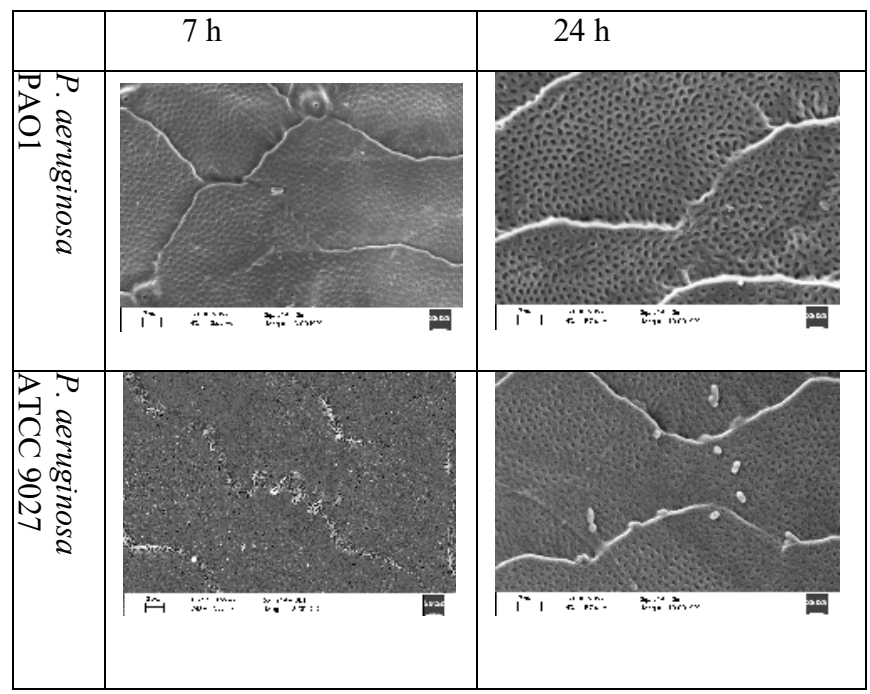

Fig. 6. SEM images of $P$. aeruginosa strains PAO1 and ATCC 9027 on the wing surface after $7 \mathrm{~h}$ and $24 \mathrm{~h}$ of incubation. 


\section{E. Quantification of DNA in supernatant}

The DNA explicitly in the supernatant was precipitated and quantified without lysing the live intact cells. The results (fig. 7) indicated that the concentration of DNA in the supernatant was $10 \mu \mathrm{g} / \mathrm{mL}$ at $7 \mathrm{~h}$ when the $P$. aeruginosa strains were incubated with coverslip. This concentration increased to $12 \mu \mathrm{g} / \mathrm{mL}$ and $16 \mu \mathrm{g} / \mathrm{mL}$ in PAO1 and ATCC 9027 respectively at $48 \mathrm{~h}$.

When $P$. aeruginosa strains were incubated with wings, the concentration of $2 \mu \mathrm{g} / \mathrm{mL}$ and $3.8 \mu \mathrm{g} / \mathrm{mL}$ at $7 \mathrm{~h}$ increased to $3.5 \mu \mathrm{g} / \mathrm{mL}$ and $4 \mu \mathrm{g} / \mathrm{mL}$ of DNA in PAO1 and ATCC 9027 respectively at $48 \mathrm{~h}$. The results suggest that ATCC 9027 released more DNA than PAO1 on both coverslip and wing.

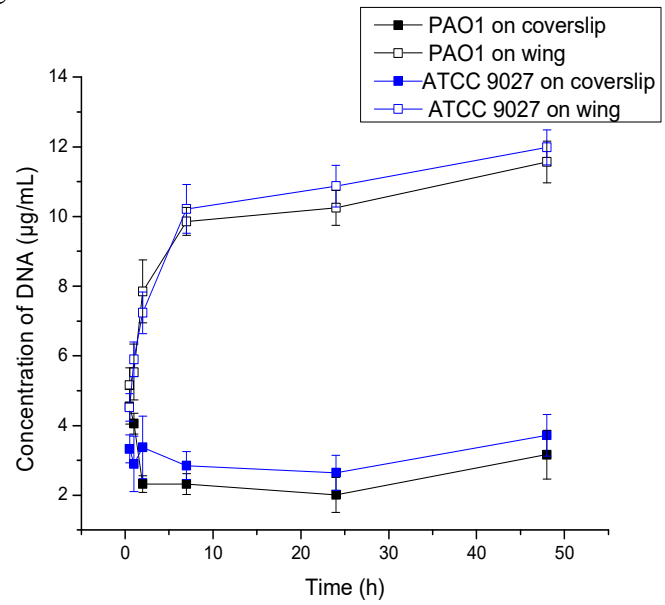

Fig. 7. Concentration of DNA in the supernatant when $P$. aeruginosa strains were incubated with coverslip and wing for $48 \mathrm{~h}$.

\section{F. Estimation of EPS}

The EPS secreted by $P$. aeruginosa strains was estimated colorimetrically using phenolsulphuric acid method. The results (fig. 8) indicated that the EPS secreted by PAO1 on coverslipincreased from $38 \mu \mathrm{g} / \mathrm{mL}$ at $7 \mathrm{~h}$ to $45 \mu \mathrm{g} / \mathrm{mL}$ at $48 \mathrm{~h}$, while in ATCC 9027, the concentration of EPS increased from $22 \mu \mathrm{g} / \mathrm{mL}$ at $7 \mathrm{~h}$ to $30 \mu \mathrm{g} / \mathrm{mL}$ at $48 \mathrm{~h}$. When the bacterial strains were incubated with wing surface, the strain PAO1 showed increase in EPS concentration from $53 \mu \mathrm{g} / \mathrm{mL}$ at $7 \mathrm{~h}$ to $40 \mu \mathrm{g} / \mathrm{mL}$ at $48 \mathrm{~h}$ and in ATCC 9027, the concentration of EPS increased from $28 \mu \mathrm{g} / \mathrm{mL}$ at $7 \mathrm{~h}$ to $40 \mu \mathrm{g} / \mathrm{mL}$ at $48 \mathrm{~h}$. Though the concentration of EPS was higher in bacteria-wing interaction than bacterial interaction with coverslip, significant differences in the EPS concentration at $48 \mathrm{~h}$ was not observed. 


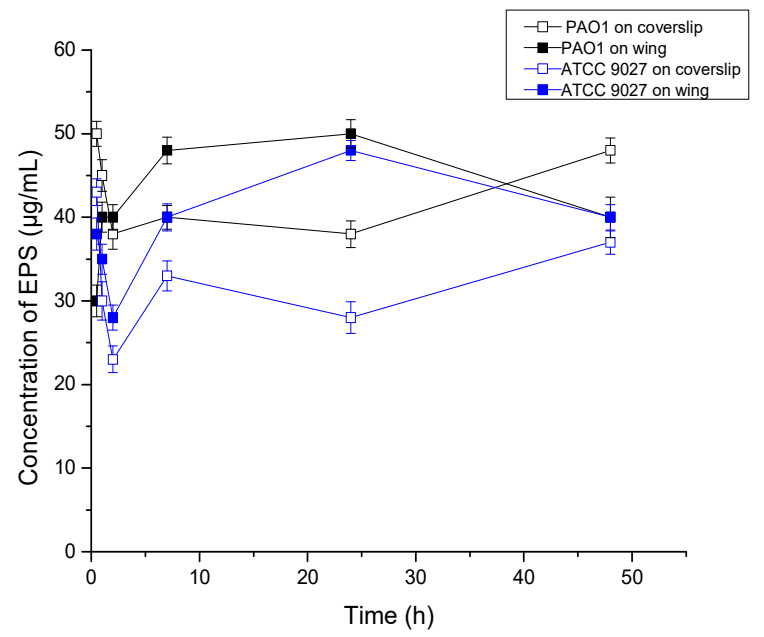

Fig. 8. Estimation of EPS secreted by P. aeruginosa strains PAO1 and ATCC 9027 when incubated with coverslip and wing for $48 \mathrm{~h}$.

Feng et al 2014 reported significant decrease in the attachment of Escherichia coli ATCC 25922 and Listeria innocua when incubated with the titanium substrate having nanopores of $15-25 \mathrm{~nm}$. E. coli $\mathrm{K} 12$ strains were observed to have deterred in expressing the surface appendage when incubated with surface containing nanoscale pores and consequently inhibiting flagellar-medicated attachment.

\section{Conclusion}

This study concludes that the nanopores on the wings of cockroach exhibited bactericidal activity against $P$. aeruginosa strains. Further experimentation on the dimensions of nanopores and material properties might facilitate in developing biomaterials with innovative and efficient surface architecture for better biological functionalities.

\section{References}

[1] Molecular analysis of Pseudomonas aeruginosa isolated from clinical, environmental and cockroach sources by ERIC-PCR. Zarei O, Shokoohizadeh L, Hossainpour H, Alikhani MY., BMC Res Notes. 2018 Sep 15;11(1):668. doi: 10.1186/s13104-018-3765-Z.PMID: 30219108

[2] First Detection of VIM-2 Metallo- $\beta$-Lactamase-Producing Pseudomonas putida in Blattella germanica Cockroaches in an Algerian Hospital.Loucif L, Cherak Z, Chamlal N, Bendjama E, Gacemi-Kirane D, Grainat N, Rolain JM.Antimicrob Agents Chemother. 2017 Jul 25;61(8):e00357-17. doi: 10.1128/AAC.00357-17. Print 2017 Aug.PMID: 28559273.

[3] First Report of German Cockroaches (Blattella germanica) as Reservoirs of CTX-M-15 ExtendedSpectrum- $\beta$-Lactamase- and OXA-48 Carbapenemase-Producing Enterobacteriaceae in Batna University Hospital, Algeria. Loucif L, Gacemi-Kirane D, Cherak Z, Chamlal N, Grainat N, Rolain JM.Antimicrob Agents Chemother. 2016 Sep 23;60(10):6377-80. doi: 10.1128/AAC.00871-16. Print 2016 Oct.PMID: 27458214. 
[4] Prevalence and Antibiotic Resistance of Gram-Negative Pathogenic Bacteria Species Isolated from Periplaneta americana and Blattella germanica in Varanasi, India. Wannigama DL, Dwivedi R, Zahraei-Ramazani A.J Arthropod Borne Dis. 2013 Dec 18;8(1):10-20. eCollection 2014.PMID: 25629061.

[5] Promise for plant pest control: root-associated pseudomonads with insecticidal activities. Kupferschmied P, Maurhofer M, Keel C.Front Plant Sci. 2013 Jul 31;4:287. doi: 10.3389/fpls.2013.00287. eCollection 2013.

[6] M. Tholkapiyan, A.Mohan, Vijayan.D.S , "A survey of recent studieson chlorophyll variation in Indian coastal waters", IOP Conf. Series: Materials Science and Engineering 993 (2020) 012041, doi:10.1088/1757-899X/993/1/012041.

[7] Gayathri Monicka,J, Dwarakesh,C. Amutha Devi, "Renewable based Multicarrier PWM Topology for Symmetric MLI" International Journal of Engineering and Technology, Vol 8 No 6 Dec 2016-Jan 2017,PP 2902- 2911 